れないようにするためには，演算ワード長を 32 ビット と大きな值にしなければならない。

このように演算部分のワード長も大きく, トーンコン トロールむ行おうとすると演算回路が大規模になってし まう.

PCM 録音機の場合と違って，比較されるアナログ方 式の高級調整卓は高機能, 高性能であり, ダイナミック レンジが $108 \mathrm{~dB}^{9}$ のものあ出現している. ディジタル方 式でこれを実現するためには 18 ビット以上の $\mathrm{AD}$ 変換 器が必要となる。また各種機能も原理的な実現手段は明 らかになりつつあるが，乙れを経済性を損なわずに実用 化するまでには多くの検討事項が残されている.

このためディジタル式は PCM 録音機の編集用として それほど高機能ではなく $\mathrm{AD}$ 変換器を含まないものがま ず実用化され，本格的な調整卓の登場はその後になるも のと思われる.

\section{5. 残響付加装置}

アナログ遅延線に対してディジタル化すれば性能劣化 なしに遅延できることに着目して古くから検討されてき た.ソニーの DRE-200010)は各種の残響モードを使用者 が設定できるとともに，いくつかの典型例を内蔵してい る. 特に従来使用されている鉄板式やスプリング式の効 果をシミュレートして出せるようになっており，てれら になれている人々にも異和感なく使用できるようになっ ている．また残響時間の周波数特性を図 3 に示すように 変化させるととができることも大きな特長である.

(昭和 56 年 9 月 3 日受付)

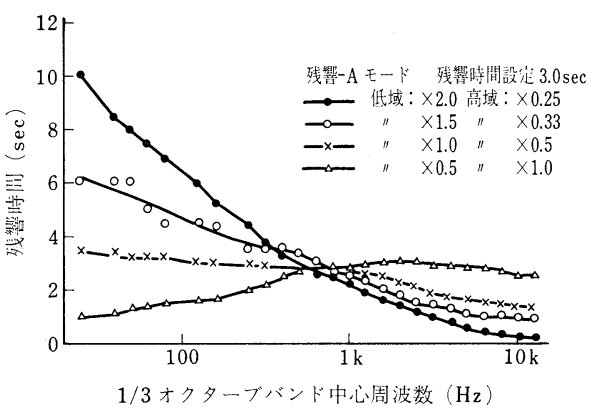

図 3 残響時間の周波数特性 ${ }^{(0)}$

\section{〔参考 文 献〕}

1）松島宏司：固定ヘッド式 PCM 録音機，テレビ誌，35, 5 (1981) 392

2) 安次嶺, 大梘, 風見, 安住, 奥出: VTR を用いた業務 用 16 ビット， 24 チャンネル PCM 録音機, 信学技報, EA 78-35 (1978.7)

3) 山田, 藤井, 斎藤, 森山：VTR を用いた業務用 PCM 録音機，テレビ学技報, VR 44-2 (1981.3)

4) 大梘正：ディジタルオーディオ編集機 DAE-1100, 放 送技術，33，11 (1980) 78

5）佐々木, 田口, 白神：ディジタルオーディオエディタ, National Technical Rep., 26, 6 (1980) 929

6) 久万俊彦: PCM 録音の電子編集装置, NHK 放送技術 報告会予稿 (1981) 5

7) 山口進: ディジタルオーディオミキサ, National Technical Rep., 26, 6 (1980) 937

8）遠藤，石沢，川崎：スタジオ用デジタルミキサの検討, 日本音響学会 55 年秋季大会, 3-5-3 (1980) 617

9) 内外ミキシングコンソールの紹介, 放送機器, 2, 4.5 (1981) 21-42

10）山内, 関口, 石坂：ディジタル残響装置 DRE-2000, 放送技術，33，11(1980) 918

\title{
3-2 今後期待されるディジタル機器
}

\section{3-2-1 ディジタル VTR}

正会員 橋 本 慶 隆†

\section{1. まえがき}

こて数年の技術進歩によって,ディジタル VTR の基 本的な性能を確認する段階はほぼ終り，フォーマットの 標準化など実用化住関する検討を行う段階になってき た. ディジタルVTRの最近の動向については当会誌 56 年 7 月号 ${ }^{1)}$ 報告したので，本文ではその後の動向と技 術的補足事項について述べる.

$\dagger$ †ニー株式会社 情報機器事業本部

“3-2 Expected Digital Equipments; 3-2-1 Digtal VTR"by Yoshitaka Hashimoto (Communication

Products Group, Sony Corporation, Tokyo)

\section{2. ディジタル VTR の開発状況}

放送用ディジタル VTR 技術は英国の IBA が 1978 年 の IBC ショウで $2 f_{s c}$ のサブナイキストサンプリング による PAL 信号をアナログ1インチ VTR と同じテー プ消費量で全画面記録できる実験機 (IBA-2)*を発表し て以来, 数年で飛躍的な進歩をとげた。この IBAの実 験機は記録データレイト $80 \mathrm{Mbit} / \mathrm{sec}$, 記録密度 10.8 $\mathrm{Mbit} / \mathrm{in}^{2}$ であったが, 1981 年 2 月にサンフランシスコで 行われたSMPTE のディジタルデモンストレーションで ソニーが発表した 14:7:7 方式のコンポーネント符号

* 本文では参考文献1) と同じ実験機の略称を用いる. 


\section{3. ディジタルテレビジョン機器の動向}

表 1 14: $7: 7$ コンポーネントディジタル VTR の諸元 (SONY-7)

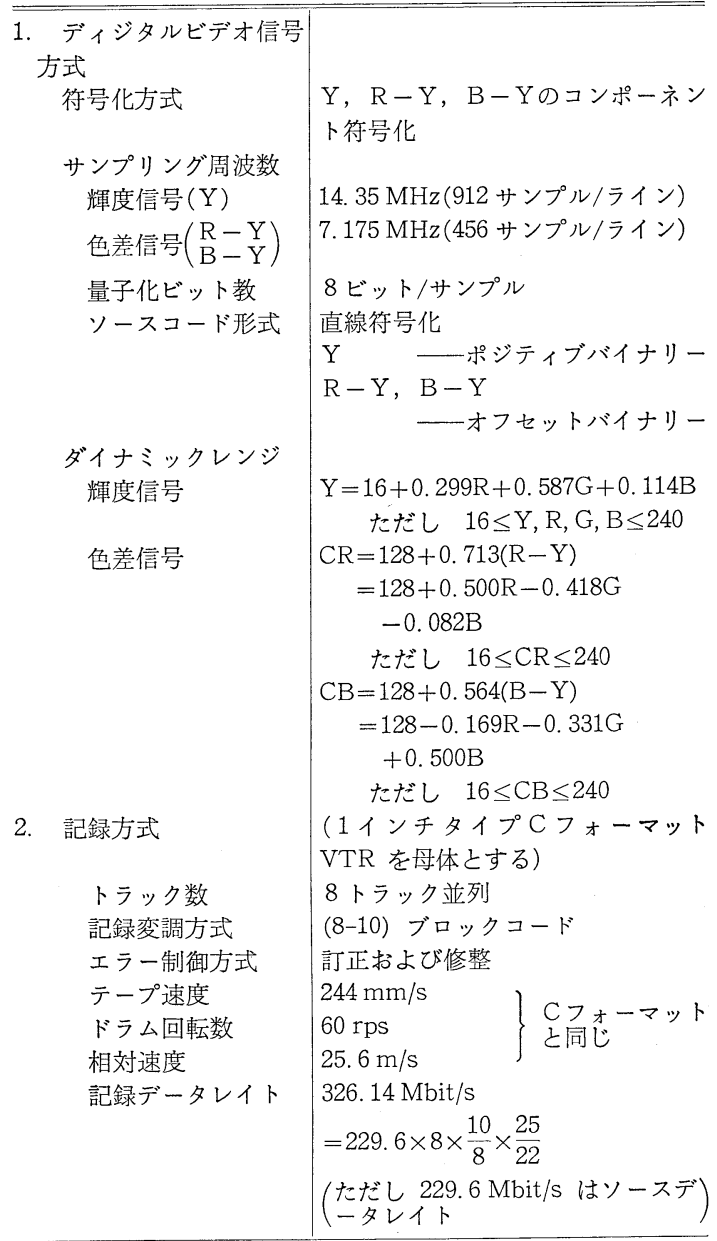

化に基づくディジタル VTR 実験機 (SONY-7)2)では記 録データレイト約 $320 \mathrm{Mbit} / \mathrm{sec}$, 記録密度 $41 \mathrm{Mbit} / \mathrm{in}^{2}$ を達成している．表 1 亿その諸元を示す.

このコンポーネントディジタル VTR 実験機 (SONY-7) は 1980 年 3 月の NAB ショウで発表されたサンプリ ング周波数 $4 f_{s c}$ のコンポジット符号化に基づく NTSC のディジタル VTR 実験機 (SONY-3) ${ }^{3)}$ を改造したもの である. SONY-3 では 1 スキャン当り 4 つのヘッドを 用いていたが, 14: 7:7のコンポーネント信号は約 2 倍 のデータレイトになるので, ヘッド構造は 8つのヘッド チップが 1 つのヘッドベースに装着された形で, 1 スキ ヤン当り 8 トラックを記録している.テープ速度はCフ オーマットと同じ值に戻したのでトラックピッチは SONY-3 と同じ約 $22.5 \mu \mathrm{m}$ であり, テープ消費量むC フォーマットと同様である．またオーディオ信号の記録 を行わず, 最短記録波長は $1.24 \mu \mathrm{m}$ とSONY-3の $1 \mu \mathrm{m}$ に比べて長くなっている.
信号処理系も基本的には SONY-3 の信号処理回路を 2 台用いた形で構成されている. 記録再生用信号処理装 置は 1 台分だけ作られたが，テープトランスポートは 2 台準備してマルチダビングの実験ができるようになって いる.さらに NTSC 信号のディジタルデコーディング とエンコーディングの実験を行うために，2 次元くし形 フィルターによる $\mathrm{Y} / \mathrm{C}$ 分離を用いたデコーダーおよび エンコーダーもとのディジタル VTR の主要部分として 作製されだ).

とのシステムにはスローモーション，ジョグモーショ ン, \pm 10 倍の高速ピクチャーサーチ機能がある.コンポ 一ネント符号化方式をとっておりコンポジット符号化の 場合に比べてエラ一修整の自由度があるため, より自然 な画像が得られた。エラー制御方式む SONY-3 と同様 に, b-adjacent 符号によるブロックエラー訂正, 水平パ リティーおよび垂直パリティーによるエラー訂正を行 い, 残留エラーは前のフィールドのデータで置き換えて いる. オーディオ信号を除いたので全コード長は 279 水 平ライン相当となるが, これをタイプCフォーマットの Aヘッド走査区間に余裕をむって記録するため（約 246 ライン相当）時間軸圧縮比は $25 / 22$ となっている.ソー スデータレイトは $229.5 \mathrm{Mbit} / \mathrm{sec}$ であるが, (8-10) ブ ロック符号を用い，かつ上記時間軸圧縮を行うと記録デ ータレイトは $326.14 \mathrm{Mbit} / \mathrm{sec}$ となる.

記録波長が比較的長くなったこと，オートトラッキン グを採用したととによって $S / N$ が向上し, ビットエラ ーレイトは $10^{-6}$ 近辺となり, エラー訂正効果が上がっ たので, 23 回のマルチダビングを行った後むエラーはほ とんご観測されなかった。 またテープの互換性, 簡単な 編集機能のテストも行われた.

今回の SMPTE デモに参加した各社の装置を相互接 続する実験む行われ，コンポーネント符号化信号に対す るインタフェースの暫定仕様で動作することも確認され た。

1981 年 2 月の SMPTE デモ以降, NAB ショウとモ ントルーテレビジョンシンポジウムがあった. NAB で は日立が $3 f_{s c}$ サンプリングの NTSCディジタルVTR ${ }^{5}$ を発表したが，モントルーではどこからむディジタル VTR の発表はなかった。これは 1979 年のモントルーシ ンポジウムでアンペックス, ボッシュ, ソニーの 3 社が 奏験機を発表したのと著しく対照的である.今は各社と むフォーマットの標準化に向かって種々の検討をはじめ たところと推察される。

\section{3. 標準化の 動向}

テレビ信号のコンポーネント符号化に関して種々のサ 
ンプリング周波数が提案されていることは先に報告した が1)，1981 年の 3 月から 5 月にかけて目まぐるしい動き があり，EBU と SMPTE が 9 月に開かれる CCIR 最 終会議に提案するために，Y信号のサンプリング周波数 を $13.5 \mathrm{MHz}, \mathrm{R}-\mathrm{Y}$ 信号と $\mathrm{B}-\mathrm{Y}$ 信号のむのを 6.75 $\mathrm{MHz}$ とすることで合意した. この辺の事情については 参考文献6) および本誌「ディジタル符号化の動向」を参 照していただきたい。

このように欧米ではビデオ信号のサンプリング周波数 についてほぼ $13.5 \mathrm{MHz}$ に落ち着くだろうとの観測か ら，実用的なディジタル VTR のフォーマットについて 議論する段階になってきた。すでに述べたように，モン トルーシンポジウムでディジタル VTR のデモはなかっ

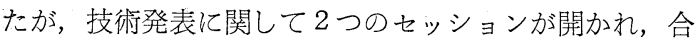

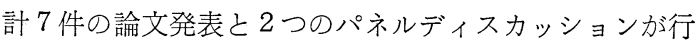
われた7). 具体的なフォーマットの提案はなかったが, 主次次のような点が議論された。

（1）世界的に統一されたフォーマットを持つことが 強く望まれており，サンプリング周波数を $13.5 \mathrm{MHz}$ に することで EBU と SMPTE が合意したのは，その第 一歩と考えられている。

（2）ディジタル VTR の編集性を考慮したディジタ ルオーディオのサンプリング周波数を早く決めたい.

（3）チャンネルコーディングに関して, 従来から知 られている $\mathrm{M}^{2} や(8-10)$ コードの他に, (8-16) コー ドが提案されたり，NRZi コードがあらためて見直され ている状況にあり，さらに検討する必要がある.

（4）新しい材料（例えば蒸着メタルテープ）の動向 を注意深く見ている必要がある.

（5）機械技術の進歩が望まれる.

(6) EBU や SMPTE のユーザーに対するアンケー トによれば, 大多数のユーザーが 1 インチアナログ VTR と同等の形状, 重量, 消費電力, 使い易さを望んで いるととと, 現在の技術レベルを考えて, 今のところテ 一プ幅は 1 インチとする, 最短記録波長は約 $1 \mu \mathrm{m}$ で 525
ラインシステムと 625 ラインシステムで同じ記録波長と することなどが，フォーマットを検討するときの基本事 項と考えられている.

この他にも技術上の課題は多いが，今後はフォーマッ トの標準化に関する議論が活発になるむのと考えられ る.

\section{4.むすび}

放送用ディジタル VTR の最近の動向について述べ た. なお，先の報告1”の参考文献の中で出典に “Digital Video-Volume 4, SMPTE”と書いたものがあるが，実 際には “Television Technology in the 80's”という表 題で SMPTE より出版されたので，乙の紙面を借りて 訂正させていただきたい

本文をまとめるにあたり，日頃御指導いただくソニー 株式会社情報機器事業本部長 森園専務, 同研究部 吉田 部長を初め, 御助言, 御協力をいただいた技術スタッフ 各位に深く感謝する.

(昭和 56 年 8 月 31 日受付)

\section{〔参考 文 献〕}

1) 橋本：ディジタル VTR の開発動向, テレビ誌, 35,7 (1981) $535-541$

2) Y. Hashimoto, et al. : Digital Component Video Recording at $230 \mathrm{Mbit} / \mathrm{sec}$, SMPTE J., July (1981)

3) M. Morizono, et al. : Digital Video Tape Recording with Increased Packing Density-Progress Report, Television Technology in the 80's, SMPTE (1981) 34-44

4) Y. Hashimoto: Digital Decoding and Encoding of the NTSC Signal at 912 Samples per Line, SMPTE J., July (1981)

5）江藤ほか：3 值記録，ファイア符号を用いた試作ディ ジタル VTR, テレビ誌, 35, 7 (1981) 563-569

6) 宇野: ディジタルテレビジョン規格をめぐるホットな 動き，放送技術， 8 (1981) 119-123

7) 12 th International Television Symposium and Technical Exhibition Montreux, May 30 June 4, 1981 の Digital Television Recording, June 2 と, Techniques used in Digital Television Recording Equipment, June 2 の 2 つ session で発表された技 術論文

\section{3-2-2 ディジタルカメラ}

\section{1. まえがき}

テレビ技術のディジタル化が急速に進んでいる中で,

$\dagger$ †本電気株式会社 基盤技術研究所

"3-2-2 Digital Color TV Camera" by Masanobu Morishita (Basic

Technology Research Laboratories, Nippon Electric Co., Ltd.,

Kawasaki)
正会員 森 下 政 信

VTR とカメラがあっとあディジタル化の遅れている装 置であった，その中でむVTR は一歩先を進み”，カメ ラはさらに遅れていた。しかしながら，カメラの分野に おいてもディジタル化の動きがまったくなかったわけで はない. 1977 年には低域成分のみディジタル化したハイ ブリッド方式 ${ }^{22}$ が提案され，1980年には 2 CCD カラー 